\title{
Analisis Simultan Neraca Pembayaran Indonesia Tahun 2009-2020
}

\author{
(Simultaneous Analysis of Indonesia's Balance of Payments 2009-2020) \\ Rulfi Annas Salamah ${ }^{1 *}$, Krismanti Tri Wahyuni ${ }^{2}$ \\ ${ }^{1,2}$ Politeknik Statistika STIS \\ Gridih 01/02, Kahuman, Polanharjo, Klaten, Jawa Tengah 57474 \\ E-mail: 211709991@stis.ac.id
}

\begin{abstract}
ABSTRAK
Sejak tahun 1970, Indonesia melibatkan diri dalam perdagangan internasional. Seluruh transaksi ekonomi antara penduduk dan non penduduk tercatat dalam neraca pembayaran Indonesia (NPI). Dari tahun 2014 hingga 2020 tw-II NPI cukup berfluktuasi, bahkan transaksi berjalan selalu mengalami defisit. Untuk mengatasi defisit diperlukan dolar lebih banyak lagi sehingga nilai tukar rupiah terdepresiasi. Penelitian ini bertujuan untuk menganalisis faktor-faktor yang mempengaruhi kinerja NPI pada tahun 2009-2020 melalui model persamaan simultan. Model persamaan simultan diperlukan untuk melihat hubungan antara NPI dan nilai tukar rupiah. Hasil penelitian menunjukkan adanya hubungan simultan antara NPI dan nilai tukar, namun NPI tidak berpengaruh signifikan terhadap nilai tukar. NPI dipengaruhi signifikan oleh nilai tukar, net export, neraca modal dan finansial, serta NPI triwulan sebelumnya, sedangkan suku bunga dan dummy Covid-19 tidak berpengaruh signifikan. Variabel yang berpengaruh signifikan terhadap nilai tukar adalah nilai tukar triwulan sebelumnya. Peningkatan nilai ekspor dan kestabilan nilai tukar rupiah diperlukan untuk memperbaiki kinerja NPI.
\end{abstract}

Kata kunci: neraca pembayaran, nilai tukar, simultan, net export, neraca modal

\begin{abstract}
Since 1970, Indonesia has been involved in international trade. All economic transactions between residents and nonresidents are recorded in Indonesia's balance of payments (BOP). From 2014 until the second quarter of 2020, the BOP was fluctuated, even the current account always deficit. To overcome the deficit, more dollars are needed so that the rupiah exchange rate depreciates. This study aims to analyze the factors that affect the BOP performance in 2009-2020 through a simultaneous equation model. Simultaneous equation model is needed to see the relationship between BOP and the rupiah exchange rate. The results showed that there was a simultaneous relationship between the BOP and the exchange rate, but the BOP had no significant effect on the exchange rate. The BOP was significantly affected by the exchange rate, net exports, capital and financial accounts, and the previous quarter's BOP, while interest rates and the dummy Covid-19 had no significant effect. The variable that has a significant effect on the exchange rate is the exchange rate of the previous quarter. An increase in the value of exports and stability in the rupiah exchange rate is needed to improve the performance of the BOP.
\end{abstract}

Keywords: balance of payment, exchange rate, simultaneous equation, net export, capital account

\section{PENDAHULUAN}

Suatu negara tidak terlepas adanya hubungan internal dan eksternal. Hubungan eksternal yang dimaknai dengan hubungan luar negeri membawa dampak dalam perekonomian suatu negara. Sejak tahun 1970, Indonesia telah menganut sistem ekonomi terbuka. Sistem ekonomi terbuka (open economy) merupakan sistem perekonomian yang melibatkan diri dalam perdagangan internasional yaitu ekspor dan impor barang atau jasa serta modal dengan negara-negara lain (Kemenkeu Learning Center, 2018). Mengacu pada BoP Manual $6^{\text {th }}$ $E d$. (2009), ekspor dan impor merupakan komponen yang digunakan dalam penghitungan neraca pembayaran. Negara dengan nilai impor yang lebih besar dari ekspornya akan mengalami defisit neraca perdagangan. Untuk mengatasi defisit neraca perdagangan diperlukan lebih banyak lagi mata uang asing sehingga akan terjadi depresiasi.

Menurut Bank Indonesia, jika ingin mengetahui surplus atau defisit suatu negara akibat transaksi ekonnomi dengan negara lain dapat menggunakan neraca pembayaran. Neraca pembayaran (NP) adalah suatu catatan sistematis dari seluruh transaksi ekonomi antara penduduk dengan bukan penduduk pada periode waktu tertentu (International Monetary Fund, 2009). Secara umum, neraca pembayaran Indonesia (NPI) menggambarkan aliran sumber daya dari Indonesia ke negara lain maupun sebaliknya. Perkembangan NPI juga menggambarkan stabilitas sektor eksternal perekonomian Indonesia. 


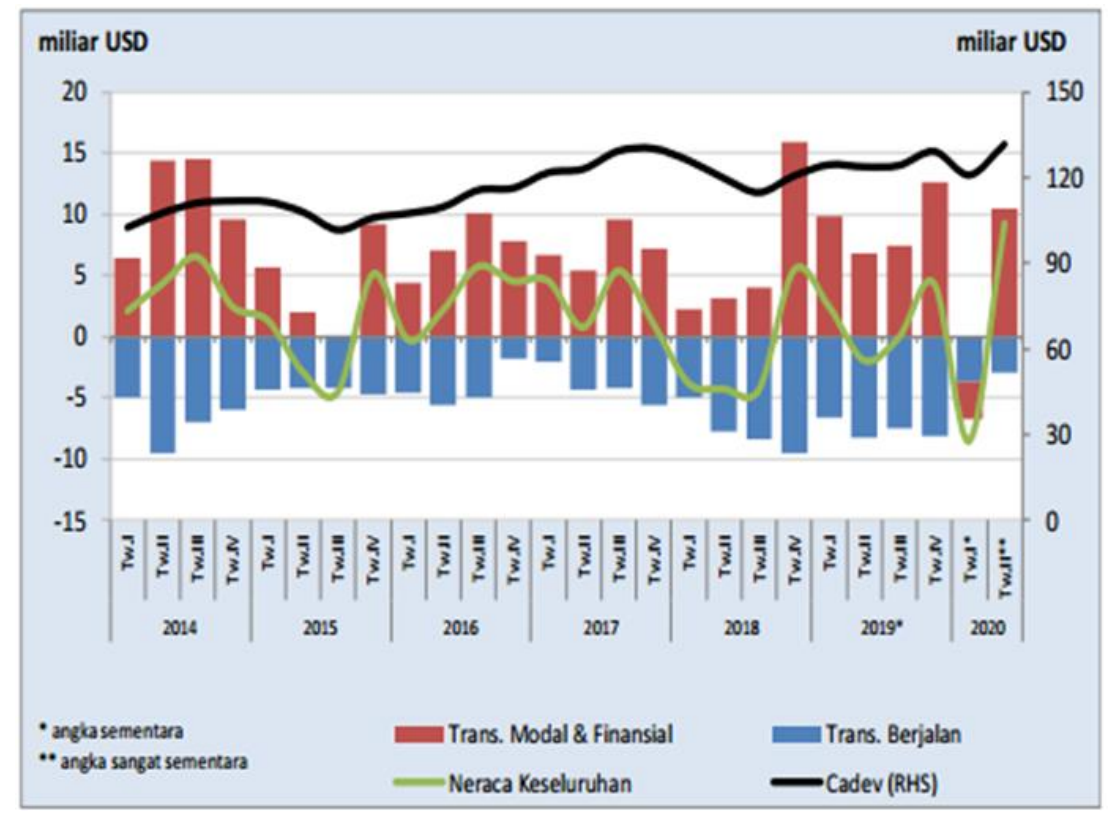

Sumber: Statistik Ekonomi dan Keuangan Indonesia, diolah.

Gambar 1. Neraca pembayaran Indonesia triwulanan dalam miliar USD, 2014.1-2020.2

Kondisi NPI pada Gambar 1 terlihat cukup berfluktuasi dari tahun 2014 hingga triwulan II tahun 2020. NPI masih kurang stabil dan relatif sering defisit. Transaksi berjalan selalu mengalami defisit sejak tahun 2014 triwulan I hingga tahun 2020 triwulan II. Namun, di tengah pandemi Covid-19 yang melanda Indonesia, pada triwulan II-2020 NPI mampu mencatat surplus sebesar USD9,2 miliar. Surplus pada neraca pembayaran (NP) inilah yang diharapkan pemerintah. Surplus pada NP dan komponennya dinilai penting untuk menunjukkan kinerja suatu negara dalam menghadapi bisnis internasional (Kahar, Suhendra, \& Suharto, 2017).

Kondisi NP mempengaruhi bertambah atau berkurangnya cadangan devisa suatu negara. Cadangan devisa akan bertambah seiring dengan surplus pada NP, begitu juga sebaliknya. Cadangan devisa akan tergerus seiring dengan defisit yang terjadi pada NP (Sugiyono, 2002). Kondisi ini akan berdampak pada nilai tukar rupiah. Permintaan dolar yang semakin meningkat untuk mengatasi defisit menyebabkan nilai tukar rupiah mengalami depresiasi. Kebutuhan mata uang asing diperlukan untuk membiayai impor dan penarikan modal dari Indonesia.

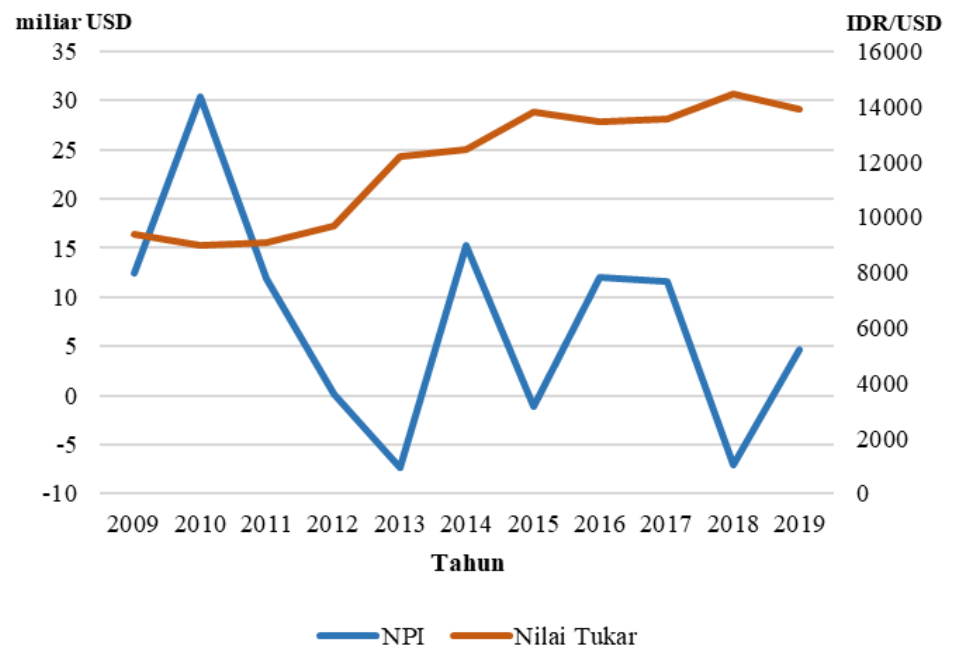

Sumber: Statistik Ekonomi dan Keuangan Indonesia dan Website IMF, diolah.

Gambar 2. Pergerakan NPI dan nilai tukar rupiah, 2009-2019

Gambar 2 menunjukkan kondisi NPI yang cenderung mengalami penurunan kinerja. Pada tahun 2013, NPI mengalami defisit sebesar USD7,3 miliar, defisit terparah sejak tahun 2009. Hal ini dipengaruhi defisit pada transaksi berjalan akibat melambatnya pertumbuhan ekonomi dunia dan menurunnya harga komoditas global (Detik Finance, 2014). Defisit ini berdampak pada menurunnya cadangan devisa. Cadangan devisa 
Indonesia mengalami penurunan sebesar 11,9 persen dari 112,8 miliar USD (tahun 2012) menjadi 99,4 miliar USD (tahun 2013). Selain itu, nilai tukar rupiah triwulan-IV tahun 2013 juga mengalami depresiasi sebesar 26 persen dibandingkan nilai tukar rupiah triwulan-IV tahun 2012. Arah pergerakan nilai tukar rupiah tehadap dolar cenderung mengalami depresiasi. Depresiasi mata uang suatu negara merupakan respon dari defisit yang terjadi pada NPI. Lonjakan nilai tukar rupiah terhadap dolar pada triwulan-IV tahun 2013, 2015, dan 2018 terjadi seiring dengan kondisi NPI yang mencapai minus.

Ekonom Inggris, John Maynard Keynes (1883-1946) mempelopori revolusi dalam pemikiran ekonomi. Keynes berpendapat bahwa neraca pembayaran tidak akan mencapai keseimbangan dengan sendirinya, namun diperlukan intervensi pemerintah. Terdapat beberapa pendekatan yang menjelaskan teori Keynes diantaranya adalah pendekatan elastisitas, pendekatan absorbsi, pendekatan kebijakan, dan pendekatan IS-LM. Berdasarkan pendekatan tersebut, cadangan devisa suatu negara dipengaruhi oleh nilai tukar, pendapatan nasional, dan suku bunga (Masdjojo, 2010).

Menurut Mundell-Fleming dalam sistem nilai tukar mengambang (floating rate), NP selalu berada dalam keseimbangan. Apabila terjadi defisit NPI maka nilai tukar rupiah akan terdepresiasi. Depresiasi rupiah akan meningkatkan permintaan ekspor sehingga NPI kembali seimbang. Sejalan dengan Syarifuddin (2015), salah satu pendekatan yang melandasi pergerakan nilai tukar adalah pendekatan fundamental yang terdiri atas kondisi paritas, pasar asset, dan neraca pembayaran. Kondisi neraca pembayaran berhubungan dengan kepemilikan aset luar negeri yang pada akhirnya akan mempengaruhi nilai tukar sehingga hubungan antara neraca pembayaran dan nilai tukar bersifat dua arah. Melalui model persamaan simultan diharapkan dapat menggambarkan pengaruh antar dua variabel ini.

Rangkuty, Novalina, dan Fauzi (2020) melakukan penelitian terkait efek simultanitas variabel moneter terhadap neraca pembayaran di lima negara pada tahun 2000-2018. Hasil penelitian menunjukkan simultanitas terjadi antara variabel kurs di lima negara terhadap neraca pembayaran di lima negara tersebut. Kurs berpengaruh negatif dan signifikan terhadap neraca pembayaran, begitu pula sebaliknya. Net export secara positif dan signifikan memengaruhi pergerakan neraca pembayaran di lima negara tersebut, sedangkan inflasi tidak signifikan. Tingkat suku bunga secara positif dan signifikan mempengaruhi kurs mata uang, sedangkan jumlah uang beredar negatif dan tidak signifikan.

Acha dan Uko (2019) melakukan penelitian tentang pemodelan persamaan simultan dari variabel ekonometrik terpilih tentang ekonomi Nigeria. Penelitian ini menunjukkan nilai tukar berpengaruh negatif terhadap neraca pembayaran, sedangkan neraca pembayaran memengaruhi nilai tukar secara positif. Susanti (2017) juga menyatakan bahwa depresiasi nilai tukar menyebabkan neraca pembayaran menjadi defisit sehingga nilai tukar berpengaruh signifikan dan negatif terhadap neraca pembayaran. Rusiadi \& Novalina (2017) juga menunjukkan secara simultan cadangan devisa sangat dipengaruhi oleh kurs dan kredit domestik. Arifin \& Mayasya (2018) menggunakan metode ARCH-M untuk menjelaskan variabel-variabel yang mempengaruhi nilai tukar rupiah. Variabel-variabel yang signifikan positif mempengaruhi nilai tukar rupiah terhadap US dolar adalah inflasi, suku bunga, indeks derajat keterbukaan ekonomi, dan volatilitas nilai tukar IDR/USD.

Penelitian ini bertujuan untuk menganalisis pergerakan neraca pembayaran Indonesia secara tahunan. Analisis simultan neraca pembayaran Indonesia dan nilai tukar rupiah juga dilakukan untuk menganalisis hubungan diantara keduanya serta faktor-faktor yang mempengaruhinya. Dengan mengetahui determinan NPI dan nilai tukar rupiah diharapkan dapat memberikan informasi kepada pemerintah dalam menyusun kebijakan untuk memperbaiki kinerja NPI dan menguatkan nilai tukar rupiah.

\section{METODE}

\section{Teori Keynesian}

Keynes berpendapat bahwa neraca pembayaran tidak akan mencapai keseimbangan tanpa intervensi dari pemerintah. Beberapa pendekatan yang berlandaskan pemikiran Keynes diantaranya yaitu pendekatan elastisitas, pendekatan absorpsi, pendekatan kebijakan, dan pendekatan IS-LM. Dalam pendekatan elastisitas, dikenal dengan istilah Marshall Lerner Condition, suatu kondisi devaluasi mata uang dapat memperbaiki neraca perdagangan jika nilai elastisitas permintaan impor dan ekspor terhadap nilai tukar riil lebih dari satu. Kemudian pendekatan absorpsi muncul sebagai perbaikan dari pendekatan elastisitas. Menurut pendekatan ini, efek devaluasi terhadap neraca perdagangan tergantung dari dampak devaluasi terhadap pendapatan dan absorpsi. Absorpsi merupakan penjumlahan dari konsumsi, investasi, dan pengeluaran pemerintah dan ekspor dikurangi impor. Devaluasi akan memperbaiki neraca perdagangan apabila kenaikan output lebih besar daripada absorpsinya (Nopirin, 1998). Pendekatan kebijakan atau policy mix memadukan expenditure reducing 
dan expenditure switching. Expenditure reducing dapat dilakukan melalui kebijakan fiskal dan moneter, sedangkan expenditure switching dilakukan melalui kebijakan perdagangan dan nilai tukar.

Perkembangan selanjutnya dikemukakan oleh Robert Mundell dan Marcus Fleming. Masdjojo (2010) mengemukakan bahwa terdapat 3 persamaan yang dibangun untuk mendapatkan persamaan neraca pembayaran yaitu persamaan IS, LM, dan neraca pembayaran. Menurut Dornbusch, Fischer, \& Startz (2011) neraca pembayaran terdiri atas neraca transaksi berjalan (current account) dan neraca kapital (capital account). Neraca transaksi berjalan tergantung pada pendapatan domestik dan luar negeri, sedangkan neraca kapital bergantung pada tingkat bunga (Masdjojo, 2010). Pendapatan domestik yang tinggi akan mendorong masyarakat untuk melakukan impor sehingga neraca perdagangan akan defisit. Apabila tingkat bunga dalam negeri lebih rendah daripada tingkat bunga dunia maka akan mendorong investor asing menanamkan modalnya di Indonesia. Arus modal yang masuk ini dapat menutup defisit neraca perdagangan sehingga NPI kembali seimbang atau bahkan mencapai surplus.

\section{Neraca Pembayaran Indonesia}

Neraca pembayaran Indonesia (NPI) merupakan catatan sistematis atas transaksi ekonomi yang terjadi antara penduduk dengan bukan penduduk Indonesia pada suatu periode tertentu. Transaksi ekonomi yang dicatat dalam NPI merupakan transaksi yang menimbulkan perpindahan kepemilikan aset dan kewajiban antara penduduk dengan bukan penduduk. Komponen NPI dibagi dalam empat neraca yaitu neraca transaksi berjalan, neraca modal, neraca finansial, dan pos cadangan devisa. Neraca transaksi berjalan menunjukkan arus barang, jasa, pendapatan primer dan pendapatan sekunder antara penduduk dan bukan penduduk. Transaksi barang dan jasa tercakup dalam neraca perdagangan (trade balance). Neraca transaksi modal mencakup transfer modal (capital transfers) dan pembelian atau penjualan aset nonfinansial yang tidak diproduksi (acquisition or disposal of nonproduced, nonfinancial assets) seperti tanah yang dijual ke kedutaan dan penjualan lisensi. Transaksi keuangan mencatat transaksi yang melibatkan aset dan kewajiban keuangan antara penduduk dengan bukan penduduk. Komponen dalam transaksi keuangan diantaranya yaitu investasi langsung dan investasi portofolio. Pos cadangan devisa menunjukkan besarnya perubahan cadangan devisa yang dikelola oleh otoritas moneter (Bank Indonesia) sehubungan dengan transaksi internasional pada periode tertentu (Sugiyono, 2002).

\section{Nilai Tukar}

Nilai tukar suatu mata uang didefinisikan sebagai harga relatif dari suatu mata uang terhadap mata uang lainnya. Menurut Syarifuddin (2015) pergerakan nilai tukar di pasar dipengaruhi oleh faktor fundamental dan non-fundamental. Faktor fundamental tercermin dari variabel ekonomi makro seperti pertumbuhan ekonomi dan inflasi. Faktor non-fundamental antara lain berupa faktor psikologi pelaku pasar dalam memperhitungkan informasi, rumor, atau perkembangan lain. Krugman, Obstfeld, \& Melitz (2014) menuliskan terdapat tiga pendekatan utama secara fundamental yang memengaruhi nilai tukar, yaitu kondisi paritas, pasar aset, dan neraca pembayaran. Konsep purchasing power parity (PPP) relatif adalah persentase perubahan nilai tukar dua negara dalam suatu periode sama dengan perbedaan inflasi di kedua negara. Selain itu konsep interest rate parity (IRP) menjelaskan bahwa nilai tukar ke depan akan ditentukan oleh besaran perbedaan suku bunga antarnegara mata uang yang diperbandingkan dengan memasukkan premi risiko maupun tidak. Pada portofolio balanced model (PBM), faktor yang menentukan nilai tukar adalah permintaan dan penawaran aset finansial. Investor/pelaku pasar valuta akan memilih portofolio yang optimal di antara berbagai aset, baik domestik maupun asing untuk mendapatkan keuntungan yang optimal. Surplus (defisit) neraca berjalan akan berhubungan dengan kenaikan (penurunan) dalam kepemilikan domestik bersih terhadap aset luar negeri (Syarifuddin, 2015). Kondisi perekonomian suatu negara yang tercermin dalam neraca pembayaran juga menjadi faktor penentu nilai tukar. Dalam kegiatan ekspor dan impor, nilai tukar memerankan peran utama sebagai pembanding harga barang dan jasa antarnegara. Neraca berjalan yang defisit dapat menyebabkan depresiasi mata uang yang kemudian berakibat pada menurunnya harga barang domestik di pasar internasional. Penurunan harga ini mendorong peningkatan daya saing sehingga dapat memicu kenaikan ekspor dan mengembalikan neraca pembayaran ke keseimbangan, bahkan mencapai surplus. 


\section{Model Persamaan Simultan}

Dalam fenomena ekonomi seringkali ditemukan hubungan sebab-akibat searah yang tidak bermakna. Terdapat suatu kondisi variabel Y ditentukan oleh X dan X ditentukan oleh Y sehingga tiap-tiap variabel tersebut saling bergantung (endogen). Model seperti inilah yang disebut dengan model persamaan simultan (simultaneosly equation model). Menurut Gujarati \& Porter (2008) model persamaan simultan dengan M variabel endogen dan $\mathrm{K}$ variabel predetermined secara umum dapat dituliskan sebagai berikut:

$$
\begin{gathered}
Y_{1 t}=\beta_{12} Y_{2 t}+\beta_{13} Y_{3 t}+\cdots+\beta_{1 M} Y_{M t}+\gamma_{11} X_{1 t}+\cdots+\gamma_{1 K} X_{K t}+u_{1 t} \\
Y_{2 t}=\beta_{21} Y_{1 t}+\beta_{23} Y_{3 t}+\cdots+\beta_{2 M} Y_{M t}+\gamma_{21} X_{1 t}+\cdots+\gamma_{2 K} X_{K t}+u_{2 t} \\
Y_{3 t}=\beta_{31} Y_{1 t}+\beta_{21} Y_{2 t}+\cdots+\beta_{3 M} Y_{M t}+\gamma_{31} X_{1 t}+\cdots+\gamma_{3 K} X_{K t}+u_{3 t} \\
\vdots \\
Y_{M t}=\beta_{M 1} Y_{1 t}+\cdots+\beta_{M, M-1} Y_{M-1, t}+\gamma_{M 1} X_{1 t}+\cdots+\gamma_{M K} X_{K t}+u_{M t} \cdots
\end{gathered}
$$

Keterangan:

$Y=$ variabel endogen

$X=$ variabel predetermined

$u=$ gangguan stokastik

$M=$ variabel endogen ke-M

$K=$ variabel predetermined $\mathrm{ke}-\mathrm{K}$

$\beta=$ koefisien dari variabel endogen

$\gamma=$ koefisien dari variabel predetermined

$t=$ observasi

Variabel endogen merupakan variabel yang bersifat stokastik dan nilainya ditentukan oleh model. Sedangkan variabel predetermined merupakan variabel yang bersifat nonstokastik dan nilainya ditentukan di luar model, terbagi menjadi variabel eksogen, lagged exogenous, dan lagged endogenous.

Dalam pengerjaannya, persamaan struktural diturunkan ke dalam persamaan bentuk tereduksi (reducedform equations). Kemudian dilakukan identifikasi untuk mengetahui perkiraan numerik dari parameter struktural yang diperoleh dari reduced-form equations sehingga diperoleh persamaan tersebut exactly identified, over-identified, atau unidentified. Menurut Gujarati \& Porter (2008) terdapat dua syarat untuk mengidentifikasi suatu persamaan yaitu order dan rank. Jika persamaan overidentified maka metode Two Stage Least Squares (2SLS) dapat digunakan untuk estimasi.

Pada penelitian ini menggunakan analisis simultan dengan dua persamaan struktural yaitu persamaan neraca pembayaran Indonesia (NPI) dan persamaan nilai tukar. Tahapan ujii yang dilakukan adalah sebagai berikut:

1. Spesifikasi dan identifikasi model persamaan struktural. Kedua persamaan struktural overidentified.

$N P I_{t}=\beta_{10}+\beta_{11} N T_{t}+\gamma_{11} N X_{t}+\gamma_{12} N M F_{t}+\gamma_{13} S B_{t}+\gamma_{14} \operatorname{COV}_{t}+\gamma_{15} N P I_{t-1}+u_{1}$

Keterangan:

$\begin{array}{ll}\beta_{10} & =\text { Konstanta } \\ N P I_{t} & =\text { Neraca pembayaran Indonesia triwulan ke-t (Juta USD) } \\ N T_{t} & =\text { Nilai tukar triwulan ke-t (IDR/USD) } \\ N X_{t} & =\text { Net export triwulan t (Triliun rupiah) } \\ N M F_{t} & =\text { Neraca modal dan finansial triwulan t (Juta USD) } \\ S B_{t} & =\text { Suku bunga triwulan t (persen) } \\ C O V_{t} & =\text { Dummy Covid-19 triwulan t } \\ N P I_{t-1} & =\text { Neraca pembayaran Indonesia triwulan sebelumnya (Juta USD) } \\ u_{1 t} & =\text { error term }\end{array}$

$N T_{t}=\beta_{20}+\beta_{21} N P I_{t}+\gamma_{21} S B_{t}+\gamma_{22} I N F_{t}+\gamma_{23} N T_{t-1}+u_{2 t}$

Keterangan:

$\beta_{20}=$ Konstanta

$N T_{t} \quad=$ Nilai tukar triwulan t (IDR/USD)

$N P I_{t} \quad=$ Neraca pembayaran Indonesia triwulan $t$ (Juta USD)

$S B_{t} \quad=$ Suku bunga triwulan $\mathrm{t}$ (persen)

$I N F_{t} \quad=$ Inflasi triwulan $\mathrm{t}$ (persen)

$N T_{t-1} \quad=$ Nilai tukar triwulan sebelumnya (IDR/USD) 
$u_{2 t}=$ error term

2. Pengujian endogenitas dengan Hausman test

3. Pengujian simultanitas dengan Hausman Spesification test

4. Estimasi model meggunakan Two Stage Least Square (2SLS)

5. Pengujian asumsi klasik: normalitas dengan Jarque-Bera test, homoskedastisitas dengan Breusch PaganGodfrey, nonautokorelasi dengan Breusch Godfrey atau LM test, dan nonmultikolinearitas dengan nilai Variance Inflation Factors (VIF) yang tidak boleh lebih besar dari 10.

6. Uji keberartian model dengan koefisien determinasi overall $F$, dan uji parsial t.

\section{Data dan Sumber Data}

Data yang digunakan dalam penelitian ini merupakan data sekunder yang diperoleh dari berbagai sumber dalam bentuk triwulanan pada periode tahun 2009 triwulan I hingga 2020 triwulan IV. Data neraca pembayaran Indonesia diperoleh dari Statistik Ekonomi dan Keuangan Indonesia (SEKI) yang diterbitkan oleh Bank Indonesia. Data nilai tukar rupiah per US Dolar diperoleh dari publikasi International Financial Statistics (IFS) dalam website International Monetary Fund (IMF). Data net export, inflasi, dan suku bunga diperoleh dari website Badan Pusat Statistik (BPS). Sedangkan variabel dummy Covid-19 dibentuk berdasarkan Surat Keputusan Kepala Badan Nasional Penanggulangan Bencana Nomor 9A Tahun 2020 tentang Penetapan Status Keadaan Tertentu Darurat Bencana Wabah Penyakit Akibat Virus Corona di Indonesia yang disahkan sejak 28 Januari 2020. Variabel dummy Covid-19 dengan nilai 0 untuk kondisi normal (sebelum terjadi pandemi Covid-19) yaitu untuk periode 2009 tw-I hingga 2019 tw-IV dan nilai 1 untuk kondisi Covid-19 yaitu untuk periode $2020 \mathrm{tw}-\mathrm{I}$ hingga tw-IV.

\section{HASIL DAN PEMBAHASAN}

\section{Pergerakan NPI dan Nilai Tukar}

Pergerakan neraca pembayaran Indonesia (NPI) menggambarkan hubungan eksternal perekonomian Indonesia. NPI merupakan penjumlahan dari neraca transaksi berjalan, transaksi modal, dan transaksi finansial. Tiga kemungkinan yang terjadi pada NPI adalah surplus, defisit, atau seimbang. Selama dua belas tahun terakhir kondisi NPI cenderung befluktuatif. NPI mengalami surplus tertinggi pada tahun 2010 yaitu sebesar USD30,3 miliar. Pertumbuhan yang tinggi ini didukung membaiknya neraca perdagangan karena ekspor komoditas nonmigas yang tumbuh dengan pesat. Hal ini menunjukkan Indonesia bisa memulihkan keadaan pasca krisis keuangan global. Perlambatan ekonomi di Amerika Serikat dan Eropa tidak berpengaruh banyak kepada ekspor Indonesia. Dalam lima tahun terakhir, 60 persen pasar ekspor Indonesia adalah negara berkembang, termasuk Asia. Pergeseran pasar ekspor Indonesia menunjukkan Indonesia tidak lagi bergantung pada negara-negara maju seperti kawasan Amerika Serikat dan Eropa (Kemenperin, 2011).

Namun, pada tahun-tahun berikutnya kinerja NPI mengalami penurunan. Tahun 2013, NPI defisit sebesar USD7,3 miliar, defisit terparah sejak tahun 2009. Pertumbuhan ekonomi dunia yang sedang melambat dan harga komoditas global yang sedang turun menyebabkan defisit neraca transaksi berjalan mencapai USD29,1 miliar. Menariknya, NPI di tahun 2020 tetap surplus meskipun sedang berada di tengah pandemi. Pada triwulan I-2020 NPI mengalami defisit sebesar USD8,5 miliar. Kemudian pada triwulan II mengalami kenaikan surplus yang signifikan hingga mencapai USD9,2 miliar. Berkurangnya defisit transaksi berjalan dan meningkatnya surplus transaksi finansial menjadi penyebab NPI tetap bertahan saat pandemi. 


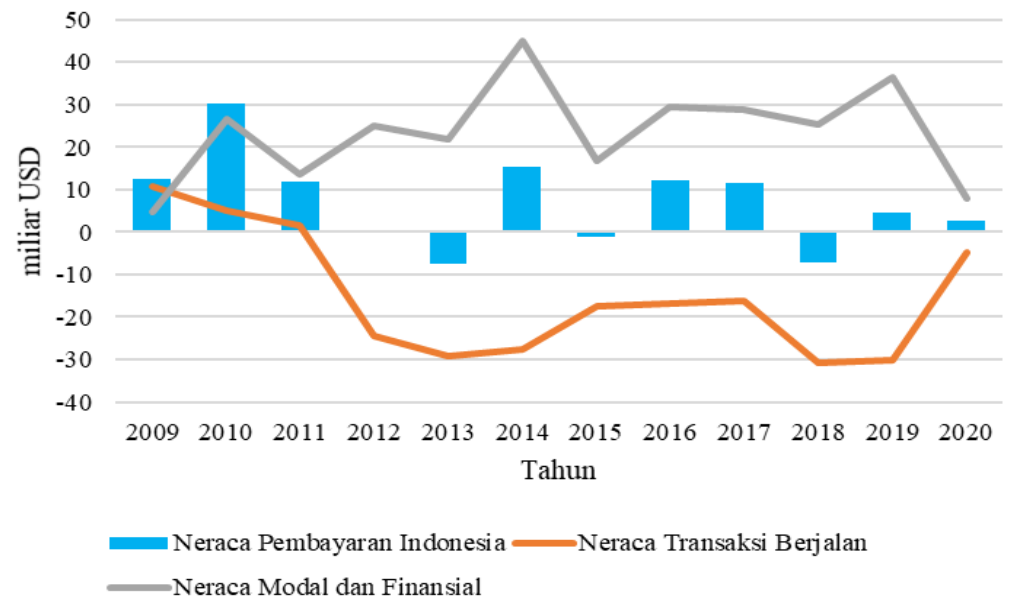

Sumber: Statistik Ekonomi dan Keuangan Indonesia, diolah.

Gambar 3. NPI dan komponennya dalam miliar USD, 2009-2020

Pada Gambar 3, sejak tahun 2012 neraca transaksi berjalan mengalami defisit setiap tahunnya. Defisit tertinggi terjadi pada tahun 2013 dan 2018 yaitu sebesar USD 29,1 miliar dan USD 30,6 miliar. Berbanding terbalik dengan neraca modal dan finansial yang selalu surplus. Pada tahun 2014, transaksi finansial mengalami surplus tertinggi selama periode penelitian yaitu sebesar USD44,9 miliar. Investasi portofolio merupakan penyumbang terbesarnya. Dibandingkan tahun sebelumnya, investasi portofolio surplus hampir 3 kali lipat. Surplus pada transaksi modal dan finansial diharapkan dapat menutup defisit pada neraca transaksi berjalan sehingga kinerja NPI dapat dipertahankan.

Selain NPI, kondisi nilai tukar rupiah juga menjadi potret interaksi ekonomi Indonesia dengan ekonomi global (Pusat Kajian Ekonomi Makro, 2015). Dalam UU No. 3 tahun 2004 pasal 7 dijelaskan bahwa tujuan Bank Indonesia adalah memelihara kestabilan nilai rupiah. Kestabilan nilai rupiah yang dimaksud adalah stabil terhadap harga barang dan jasa dan stabil terhadap mata uang negara lain. Meskipun saat ini Indonesia menganut sistem nilai tukar mengambang bebas (free floating exchange rate system) namun kestabilan nilai tukar perlu dijaga untuk mencapai stabilitas harga dan sistem keuangan.

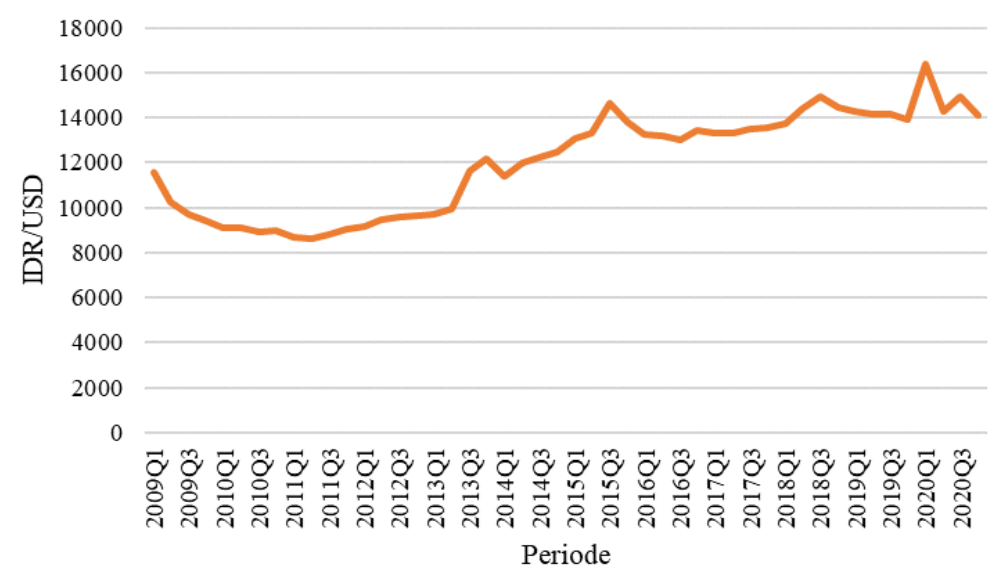

Sumber: Statistik Ekonomi dan Keuangan Indonesia, diolah.

Gambar 4. Nilai tukar rupiah terhadap US dolar triwulanan, 2009-2020

Pada Gambar4, nilai tukar rupiah cukup berfluktuatif dan cenderung mengalami depresiasi. Depresiasi terparah terjadi pada tahun 2020 triwulan I yaitu mencapai 16.367 rupiah/USD yang kemudian menguat kembali di triwulan berikutnya. Depresiasi ini terjadi karena pandemi Covid-19 yang mulai menyebar di Indonesia dan meningkatnya resiko ketidakpastian global. Namun, seiring berjalannya waktu dan pandemi Covid-19 dapat mulai ditangani, pasar keuangan global menjadi lebih stabil dibandingkan triwulan I-2020. Menguatnya sisi internal perekonomian yang ditandai dengan terjaganya inflasi di 0,45 persen, suku bunga yang tergolong rendah yaitu 3,75 persen, dan neraca transaksi berjalan yang berada di kondisi surplus dinilai dapat menahan pelemahan nilai tukar rupiah. 


\section{Estimasi Model Persamaan Simultan}

Sebelum melakukan estimasi model menggunakan Two Stage Least Squares (2SLS), terlebih dahulu dilakukan pengujian endogenitas dan simultanitas terhadap kedua persamaan struktural. Nilai probability statistik uji t dari estimasi variabel NPI dan nilai tukar kurang dari taraf uji yang digunakan yaitu 1 persen atau 0,01 sehingga OLS tidak dapat diterapkan dalam estimasi (Gujarati dan Porter, 2008). Kemudian, nilai probability statistik uji t dari estimasi variabel eror menunjukkan kurang dari 0,01 sehingga dapat disimpulkan bahwa terdapat masalah simultanitas. Selain itu, berdasarkan identifikasi kedua persamaan overidentified sehingga metode estimasi yang digunakan untuk menyelesaikan persamaan simultan adalah Two Stage Least Squares (2SLS).

Pada model yang terbentuk dari metode 2SLS dilakukan uji asumsi klasik. Nilai probability Jarque Bera test pada persamaan $N P I_{t}$ lebih besar dari 0,01 sedangkan pada persamaan $N T_{t}$ kurang dari 0,01 . Artinya residual pada persamaan $N P I_{t}$ memiliki distribusi normal, sedangkan residual pada persamaan $N T_{t}$ tidak berdistribusi normal jika mengikuti uji tersebut. Namun, dalam penelitian ini digunakan asumsi Central Limit Theorem (CLT) sehingga dapat digunakan untuk estimasi. Probability uji Breusch-Pagan-Godfrey pada kedua persamaan lebih besar dari 0,01. Kemudian, probabilitas uji Breusch-Godfrey atau LM test pada kedua persamaan juga lebih besar dari 0,01. Artinya, pada tingkat kepercayaan 99 persen, residual pada kedua persamaan memiliki varians konstan (homoskedastisitas) dan tidak terjadi autokorelasi. Selain itu, nilai Variance Inflation Factors (VIF) setiap variabelnya menunjukkan kurang dari 10 sehingga tidak terdapat masalah multikolinearitas dalam kedua persamaan tersebut

Tabel 1. Hasil uji asumsi klasik

\begin{tabular}{|c|c|c|c|c|c|c|}
\hline \multirow[t]{3}{*}{ Uji } & \multicolumn{6}{|c|}{ Persamaan Struktural } \\
\hline & \multicolumn{3}{|c|}{$N P I_{t}$} & \multicolumn{3}{|c|}{$N T_{t}$} \\
\hline & Statistic & Prob. & Keputusan & Statistic & Prob. & Keputusan \\
\hline Jarque-Bera & 0,8137 & 0,6657 & Gagal Tolak $H_{0}$ & 14,6998 & 0,0006 & Tolak $H_{0}$ \\
\hline $\begin{array}{l}\text { Breusch-Pagan- } \\
\text { Godfrey }\end{array}$ & 9,2107 & 0,1621 & Gagal Tolak $H_{0}$ & 5,9102 & 0,2059 & Gagal Tolak $H_{0}$ \\
\hline $\begin{array}{c}\text { Breusch-Godfrey } \\
\text { VIF }>10\end{array}$ & 8,5428 & 0,0140 & $\begin{array}{c}\text { Gagal Tolak } H_{0} \\
\text { Tidak Ada }\end{array}$ & 3,0623 & 0,2163 & $\begin{array}{c}\text { Gagal Tolak } H_{0} \\
\text { Tidak Ada }\end{array}$ \\
\hline
\end{tabular}

Hasil estimasi persamaan neraca pembayaran Indonesia dengan metode Two Stage Least Squares (2SLS) dapat dituliskan sebagai berikut:

$$
\begin{aligned}
& \widehat{N P I_{t}}=-582,83-0,67 N T_{t}{ }^{*}+71,10 N X_{t}{ }^{*}+0,79 N M F_{t}{ }^{*}+413,00 S B_{t}+1297,04 \operatorname{COV}_{t}+ \\
& 0,26 N P I_{t-1}{ }^{*}
\end{aligned}
$$

Nilai koefisien determinasi yang disesuaikan ( $R^{2}$ adjusted) sebesar 69,86 persen berarti sekitar 69 persen keragaman neraca pembayaran Indonesia (NPI) dapat dijelaskan oleh nilai tukar, net export, neraca modal dan finansial, suku bunga, dummy Covid-19, dan NPI sebelumnya. Sisanya sebesar 30,12 persen dijelaskan oleh faktor-faktor lain di luar model. Nilai probability $F$ statistic menunjukkan 0,000 yang menghasilkan keputusan tolak $H_{0}$, artinya secara statistik variabel nilai tukar, net export, neraca modal dan finansial, suku bunga, dummy Covid-19, dan NPI triwulan sebelumnya bersama-sama mempengaruhi variabel neraca pembayaran Indonesia secara signifikan.

Net export, neraca modal dan finansial, dan neraca pembayaran triwulan sebelumnya berpengaruh positif dan signfikan terhadap neraca pembayaran Indonesia. Hal ini sejalan dengan penelitian Rangkuty, Novalina, \& Fauzi (2020) yang menyatakan bahwa kegiatan ekspor impor yang meningkat dapat mendorong surplus neraca pembayaran di Indonesia. Selain itu, surplus pada neraca modal dan finansial juga dapat menopang ketahanan eksternal Indonesia. Posisi neraca pembayaran periode sebelumnya menjadi dasar kebijakan yang diambil oleh pemerintah atau Bank Indonesia agar kinerja NPI tetap dapat dipertahankan.

Variabel nilai tukar rupiah mempengaruhi neraca pembayaran Indonesia secara negatif signifikan. Kenaikan nilai tukar rupiah per US dolar (depresiasi) menyebabkan harga mata uang rupiah relatif turun dibandingkan dolar sehingga investor asing akan menarik dananya dari Indonesia. Arus modal keluar menyebabkan penurunan neraca modal dan finansial sehingga menurunkan kinerja neraca pembayaran (Susanti, 2017).

Variabel suku bunga dan dummy Covid-19 tidak berpengaruh signifikan terhadap neraca pembayaran Indonesia. Sejalan dengan penelitian Hermawan (2006) neraca pembayaran Indonesia mempengaruhi suku bunga, namun tidak sebaliknya. Pandemi Covid-19 yang melanda Indonesia dan negara-negara di dunia tidak 
membuat NPI terpuruk. Kuatnya permintaan domestik yang mendorong pertumbuhan ekonomi membuat kinerja NPI tidak terpengaruh adanya pandemi Covid-19.

Pada persamaan nilai tukar diperoleh estimasi parameternya sebagai berikut:

$\widehat{N T}_{t}=580,36-0,04 N P I_{t}+26,36 S B_{t}-174,90 I N F_{t}+0,95 N T_{t-1} *$

Koefisien determinasi yang disesuaikan ( $R^{2}$ adjusted) menunjukkan nilai 0,9165 berarti 91,65 persen keragaman nilai tukar dapat dijelaskan oleh neraca pembayaran Indonesia, suku bunga, inflasi, dan nilai tukar triwulan sebelumnya. Sisanya 8,35 persen dijelaskan oleh faktor lain di luar model. Nilai probability $F$ statistic menunjukkan 0,000 yang menghasilkan keputusan tolak $H_{0}$, artinya secara statistik variabel NPI, suku bunga, inflasi, dan nilai tukar triwulan sebelumnya bersama-sama mempengaruhi variabel nilai tukar secara signifikan.

Variabel nilai tukar triwulan sebelumnya berpengaruh positif dan signifikan terhadap nilai tukar triwulan berjalan. Depresiasi rupiah pada triwulan sebelumnya akan berdampak pada depresiasi rupiah triwulan berjalan. Informasi terkait nilai tukar periode sebelumnya akan menentukan nilai tukar pada periode berjalan (Rasbin, 2015). Sejalan dengan penelitian Arifin \& Mayasya (2018) bahwa volatilitas nilai tukar berpengaruh signifikan positif terhadap nilai tukar. Di pasar modal, investor akan melihat riwayat nilai tukar suatu negara sebelum memutuskan berinvestasi di negara tersebut. Tingginya minat investor untuk menanamkan modal dapat berdampak pada capital inflow sehingga nilai tukar rupiah akan menguat.

Secara statistik, neraca pembayaran Indonesia, suku bunga, dan inflasi tidak memiliki pengaruh yang signifikan terhadap nilai tukar. Syarifuddin (2015) menjelaskan di dalam portofolio balanced model (PBM), neraca transaksi berjalan dapat mempengaruhi nilai tukar melalui kepemilikan bersih domestik terhadap aset luar negeri yang kemudian akan mempengaruhi kekayaan negara dan posisi nilai tukar. Dalam penelitian Arifin \& Mayasya (2018), suku bunga dan inflasi memiliki arah hubungan yang positif dengan nilai tukar yang berarti kenaikan suku bunga dan inflasi akan diikuti depresiasi rupiah. Namun, fenomena di Indonesia pada tahun 2009 tw-I hingga 2020 tw-IV menunjukkan hal yang berbeda. Suku bunga dalam negeri cenderung mengalami penurunan, namun nilai tukar rupiah justru mengalami peningkatan atau depresiasi. Sama halnya dengan variabel inflasi. Kondisi inflasi di Indonesia cenderung stabil namun nilai tukar rupiah justru semakin terdepresiasi.

Pada persamaan (7), terlihat net export dan neraca modal dan finansial berpengaruh terhadap neraca pembayaran Indonesia. Setiap kenaikan net export dan neraca modal dan finansial sebesar 1 satuan akan meningkatkan neraca pembayaran masing-masing sebesar USD4.963,7 juta dan USD790 ribu (konversi USD1 = Rp14.324). Hal ini menunjukkan bahwa surplus pada neraca pembayaran lebih besar dipengaruhi oleh surplus pada net export (neraca perdagangan) dibanding neraca modal dan finansial, dengan asumsi variabel lain konstan. Depresiasi nilai tukar akan meningkatkan ekspor sehingga menambah saldo neraca pembayaran. Namun, pada persamaan NPI variabel nilai tukar berpengaruh negatif terhadap NPI. Koefisien nilai tukar sebesar 0,67 berarti setiap kenaikan 1 IDR/USD atau depresiasi sebesar 1 rupiah per dolar akan mengurangi saldo neraca pembayaran sebesar USD670 ribu, sedangkan kenaikan net export sebesar 1 rupiah akan meningkatkan NPI sebesar USD71,1 $\times 10^{12}$ juta. Hal ini menunjukkan bahwa pengaruh net export terhadap NPI lebih besar dibandingkan pengaruh nilai tukar, dengan asumsi variabel lain konstan. Variabel dummy Covid-19 tidak memiliki pengaruh yang signifikan terhadap neraca pembayaran. Kinerja NPI tetap terjaga ditengah gejolak pasar keuangan akibat pandemi Covid-19. Nilai tukar berpengaruh signifikan terhadap neraca pembayaran Indonesia, namun tidak sebaliknya. Pada persamaan (8), nilai tukar dipengaruhi signifikan oleh nilai tukar triwulan sebelumnya. Variabel fundamental makro ekonomi lainnya yaitu inflasi dan suku bunga tidak memiliki pengaruh signifikan terhadap nilai tukar.

Peran neraca perdagangan lebih besar dibandingkan neraca modal dan finansial dalam menyumbang surplus neraca pembayaran. Meningkatnya ekspor dan menurunnya impor akan meningkatkan saldo neraca pembayaran. Selain itu, melemahnya rupiah terhadap dolar juga akan mengurangi saldo neraca pembayaran. Untuk itu pemerintah perlu memperhatikan kekuatan neraca perdagangan dan nilai tukar. Di sisi neraca perdagangan, pemerintah perlu meningkatkan dan menguatkan eskpor produk maupun jasa sehingga neraca perdagangan dapat mencapai surplus. Dalam satu dekade ke depan, Asia diperkirakan menjadi kawasan penyumbang perdagangan global terbesar (Antara News, 2019). Pergeseran pasar ekspor Indonesia ke kawasan Asia menjadi langkah awal untuk memperluas pasar dan meningkatkan nilai ekspor. Di sisi nilai tukar, pemerintah perlu menjaga stabilitas dan meningkatkan kekuatan nilai tukar rupiah sebagai upaya membangun kepercayaan investor terhadap nilai tukar rupiah. Pola pikir yang melihat ke belakang (backward 
looking) menyebabkan agen ekonomi mempertimbangkan data historis nilai tukar rupiah sebagai prediksi nilai tukar ke depan (Rasbin, 2015).

\section{KESIMPULAN}

Pergerakan neraca pembayaran Indonesia (NPI) tahunan cenderung berfluktuasi meskipun dominan mengalami surplus. Neraca transaksi berjalan cenderung mengalami defisit, sedangkan neraca modal dan finansial selalu surplus. Secara statistik, terdapat hubungan simultan antara NPI dan nilai tukar. Variabel net export, neraca modal dan finansial, serta NPI triwulan sebelumnya berpengaruh signifikan dan positif terhadap NPI. Sedangkan nilai tukar rupiah terhadap dolar berpengaruh signifikan dan negatif terhadap NPI. Variabel nilai tukar hanya dipengaruhi signifikan oleh nilai tukar triwulan sebelumnya. NPI, suku bunga, dan inflasi tidak berpengaruh signifikan terhadap nilai tukar rupiah per dolar.

\section{DAFTAR PUSTAKA}

Acha, C. K., \& Uko, O. U. (2019). Simultaneous Equation Modeling of Selected Econometrics Variables on The Nigerian Economy. Benin Journal of Statistics, 2, 76-84.

Antara News. (2019, September 5). Dipetik Juli 14, 2021, dari https://www.antaranews.com/berita/1047044/pengamat-pasar-asia-jadi-potensi-tujuan-ekspor-indonesia

Arifin, S., \& Mayasya, S. (2018, April). Faktor-faktor yang Mempengaruhi Nilai Tukar Rupiah Terhadap Dolar Amerika Serikat. Jurnal Ekonomi-Qu, 8(1).

Detik Finance. (2014, Februari 16). detikFinance. Dipetik April 7, 2021, dari https://finance.detik.com/moneter/d-2498849/neraca-pembayaran-indonesia-defisit-rp-73-triliun-di2013

Dornbusch, R., Fischer, S., \& Startz, R. (2011). Macroeconomics (11th ed.). New York: The McGraw-Hill.

Gujarati, D. N., \& Porter, D. C. (2008). Basic Econometrics (5th ed.). New York: The Mc-Graw Hill.

Hermawan, W. (2006, Agustus). Pengujian Kausalitas Antara Tingkat Bunga dan Neraca Pembayaran di Indonesia Tahun 1999.1-2000.2. Bina Ekonomi, 10(2).

International Monetary Fund. (2009). Balance of Payments and International Investment Position Manual (6th ed.). Washington, D.C.

Kahar, G. N., Suhendra, I., \& Suharto, U. S. (2017). Analisis Faktor-faktor yang Mempengaruhi Neraca Pembayaran di Indonesia Tahun 1986-2016. Jurnal Ekonomi-Qu, 7.

Kemenperin. (2011, September 23). Kementerian Perindustrian. Retrieved April 10, 2021, from https://kemenperin.go.id/artikel/825/Ekspor-RI-

Krugman, P. R., Obstfeld, M., \& Melitz, M. J. (2014). International Economics Theory and Policy (10th ed.). Edinburgh Gate: Pearson Education.

Masdjojo, G. N. (2010). Kajian Pendekatan Keynesian dan Monetaris Terhadap Dinamika Cadangan Devisa Melalui Penelusuran Neraca Pembayaran Internasional: Studi Empiris di Indonesia Periode 1983-2008 [Disertasi]. Semarang: Universitas Diponegoro.

Nopirin. (1998). Pertumbuhan Ekonomi dan Neraca Pembayaran Indonesia 1980-1996 Suatu Pendekatan Keynes dan Monetarist.

Pusat Kajian Ekonomi Makro. (2015). Kajian Neraca Pembayaran dan Nilai Tukar Tahun 2014. Kementerian Keuangan, Badan Kebijakan Fiskal, Jakarta.

Rangkuty, D. M., Novalina, A., \& Fauzi, A. M. (2020, Mei). Efek Simultanitas Variabel Moneter Terhadap Neraca Pembayaran di Lima Negara. Jurnal Sekuritas, 3(3), 208-218.

Rasbin. (2015). Pengaruh Variabel-variabel Fundamental Makroekonomi, Nonekonomi, dan News (Berita) Terhadap Pergerakan Nilai Tukar Rupiah Periode 2004-2014. Jurnal Ekonomi \& Kebijakan Publik, 6(2), 123-134.

Rusiadi, \& Novalina, A. (2017). Kemampuan Keynesian Balance of Payment Theory and Monetary Approach Balance of Payment Mendeteksi Keseimbangan Neraca Perdagangan Indonesia.

Sugiyono, F. (2002). Neraca Pembayaran Konsep, Metodologi, dan Penerapan. Jakarta: Pusat Pendidikan dan Studi Kebanksentralan.

Susanti, R. (2017, Juli). Penerapan Metode 2SLS (Two Stage Least Square) Pada Persamaan Simultan Untuk Persamaan Perdagangan Luar Negeri dan Neraca Pembayaran. Jurnal Ekonomi \& Bisnis Dharma Andalas, 19(2).

Syarifuddin, F. (2015). Konsep, Dinamika dan Respon Kebijakan Nilai Tukar di Indonesia. Jakarta: BI Institute. 